\title{
Determinant Factors of Pneumonia among Toddlers
}

\author{
Muchsin Maulana ${ }^{1}$, Dwi Rahmatun Handari ${ }^{2}$, Septian Emma Dwi Jatmika ${ }^{3}$, Hermin Sunarti ${ }^{4}$ \\ ${ }^{1,3}$ Faculty of Public Health, Universitas Ahmad Dahlan, Indonesia \\ ${ }^{2} \mathrm{CV}$. Adi Nugraha, Indonesia \\ ${ }^{4}$ Public Health Center Gondomanan, Yogyakarta, Indonesia
}

\begin{tabular}{l} 
Article Info \\
\hline Article history: \\
Received Dec 21, 2017 \\
Revised Feb 26, 2018 \\
Accepted Mar 15, 2018 \\
\hline
\end{tabular}

\section{Keyword:}

Pneumonia

Presence of smokers

Residential density

Toddlers

Ventilation

\begin{abstract}
Pneumonia still becomes a public health problems that causing pain and death on toddlers. There are many factors which may influence the increase of pneumonia incidence on toddlers, from the aspect of kid individuals and house anvironment such as ventilation, residential density and the presence of smokers. In 2016 found 760 cases of pneumonia that took place in Yogyakarta Country. One area of this district with high influence of pneumonia is Public Health Center of Gondomanan, this area increased the number of pneumonia incidence in 2014-2016. This research used Cross Sectional research design with Chi Square analysis. The sample of this research is 54 respondents were obtained by Purposive Sampling technique. Instrument is used questionnaired to measure ventilation, residential density and the presence of smokers observation. Showed that there was a correlation between ventilation $(p=0.000 ; R P=2.786)$, residential density $(p=0.007$; $\mathrm{RP}=2.043)$, the presence of smokers $(\mathrm{p}=0.002$; $\mathrm{RP}=2.2)$ with pneumonia incidence on toddlers, in the Area of Puskesmas Gondomanan, Yogyakarta. Ventilation, residential density, and the presence of smokers is Correlation with pneumonia incidence on toddlers in one area of Yogyakarta.
\end{abstract}

Copyright $\odot 2018$ Institute of Advanced Engineering and Science. All rights reserved.

\section{Corresponding Author:}

Muchsin Maulana,

Department of Public Health Science,

Faculty of Public Health, Universitas Ahmad Dahlan

Jl. Prof. Dr. Soepomo S.H, Warungboto, Umbulharjo, Yogyakarta, Indonesia 55164.

Email: muchsin.maulana@ikm.uad.ac.id

\section{INTRODUCTION}

Pneumonia is an acute infection of the lung tissue (alveoli). Pneumonia can occur in ordinary children along with acute infection of the bronchus. Pneumonia is called the number 1 killer (killer number one child) because it is one of the biggest health problems and contributors of toddlers. In developing countries pneumonia is a neglected disease (diseases abandoned), because so many children are infected with pneumonia but very little attention is given to overcome the problem of this pneumonia case [1]. Symptoms of this disease are in the form of rapid breathing and shortness of breath, caused by sudden inflamed lung. Breathing speed is 60 times per minute in children aged $<2$ months, 50 times per minute or more in children aged 2 months to less than ome year, and 40 times per minute or more in children aged one year to less than five years [2].

The World Health Organization (WHO) estimates that pneumonia accounts for $20 \%$ of deaths in infants worldwide, about 1.2 million per year. WHO also stated that the incidence of childhood pneumonia to children under five in developing countries amounted to 151.8 million. Globally there are 1.6 to 2.2 million toddlers mortality due to pneumonia each year, mostly in developing countries where $70 \%$ are in Africa and Southeast Asia [3].

Disease and Environmental Health Indonesian Ministry of Health, in 2015 estimated 5.9 million under fives died caused by pneumonia. And the results of the Sample Registration System (SRS) in 2014 
stated that pneumonia is the number 3 cause of death in infants, the number of cases of childhood pneumonia reported in 2014 is 600.682 cases and 32.025 of which are severe pneumonia. Based on basic health research data in 2007 pneumonia disease occupied 2nd place as cause of infant and toddler mortality after diarrhea and occupied 3rd place as cause of death in neonates [4].

Pneumonia is still one of the health problems for toddlers especially in Yogyakarta Special Region. In 2011 found 1739 cases and increased in 2012 that amounted to 2936 cases [5]. Based on the data of the annual report of the Infectious Disease Control and Infectious Diseases of Yogyakarta City Health Office, the number of pneumonia incidents in under-fives in all Public Health Centerin Yogyakarta City in 2016 was 760 cases. Public Health Center Gondomanan is one of the health centers with high pneumonia cases that is recorded as 101 cases in 2016, when viewed from the trends of the last 3 years of disease in 2014, 2015 and 2016. Number of cases of pneumonia to toddlers in Public Health Center Gondomanan increased, in 2014 discovery cases of pneumonia toddlers recorded 44 cases, in 2015 recorded 90 cases and in 2016 recorded 101. The number is a case of pneumonia found and directly addressed [6].

Risk factors that can cause pneumonia are environmental factors and individual factors of the child. Environmental factors include indoor air pollution that can come from cigarette smoke, home ventilation and population density. While the individual factors of children such as age, birth weight, nutritional status, vitamin A and immunization status [7].

Houses with unqualified ventilation can cause obstructed air circulation from the inside out in creating conditions in the house to become damp, this situation will be a disease-causing disease that is in the home is easy to breed and difficult to get out so that the occupants are at risk of contact with bacteriabacteria are addressed toddlers who still have immune system that has not been perfect. High occupancy density will also affect occupant health, there are sick residents will accelerate the transmission and transmission of disease. The presence of smokers in the home can affect negatively for family members, Indonesia is a country with an active smoker number of $27.6 \%$ with 65 million smokers or 225 billion cigarettes per year [2]. Cigarettes are toxic substances that have a very harmful effect on active smokers and passive smokers, publications in infants exposed to tobacco smoke over long periods of time because cigarette smoke contains some chemicals such as nicotine, tar and carbon monoxide [8].

\section{RESEARCH METHOD}

The type of this research is observational analytic research. This research employed Cross sectional research design. In Cross sectional design the researcher is learning the relation between independent variable with dependent variable (effect) by doing the measurement at a certain period [9]. In this study, it will be examined the relationship between home ventilation, occupant density and the presence of smokers with the incidence of pneumonia in infants in the working area of Gondomanan Health Center Yogyakarta. The population in this research was all toddlers who visited January to April 2017 at Gondomanan Health Center as many as 158 toddler. The samples that used in this study were selected according to the criteria by the researcher who visited January to April 2017 at Gondomanan Health Center. The number of samples is 54 toddlers, it taken using non probability sampling technique that is purposive sampling. The research instrument that used is questionnaire. The analysis that used is univariate analysis to know the frequency distribution of each variable that studied and bivariate analysis to know the relation between variable. The test that used is Chi-square test.

\section{RESULTS AND ANALYSIS}

\subsection{Result}

\subsubsection{Univariate analysis}

Univariate analysis conducted to know the frequency distribution of variables that researched that are gender and age of toddler. Table 1 provides data regarding characteristics of respondents by sex and age among toddlers. Table 1 shows from 54 respondents that researched, based on the distribution that according to gender of toddler showed woman as many as 29 toddlers with percentage $53.71 \%$ and man as many as 25 toddlers with percentage $46.29 \%$. The distribution based on the age of toddler showed that the majority of respondents are in the age group 1-24 months that is as many as 35 toddlers $(64.83 \%)$, whereas the lowest respondents were in the age group 37-59 months is nine toddlers $(16.67 \%)$. 
Table 1. Frequency Distribution Characteristics of Respondents by Sex and Age in Toddlers

\begin{tabular}{lcc}
\hline Characteristics of Respondents & Amount & Percentage (\%) \\
\hline Gender of toddler & & \\
Girl & 29 & 53.71 \\
Boy & 25 & 46.29 \\
Amount & 54 & 100 \\
Age of toddler & & \\
1-6 months & 35 & 64.83 \\
25-36 months & 10 & 18.50 \\
37-59 months & 9 & 16.67 \\
Amount & 54 & 100 \\
\hline
\end{tabular}

Table 2 shows Frequency Distribution of Pneumonia for Toddlers in Gondomanan Health Center Yogyakarta. Based on the Table 2 is known that the amount of toddler that having pneumonia is more than toddler without pneumonia. Toddlers who suffered pneumonia were 32 toddlers $(59.3 \%)$, and respondents without pneumonia as many as 22 toddlers (40.7).

Table 2. Frequency Distribution of Pneumonia for Toddlers

\begin{tabular}{cccc}
\hline No & Pneumonia & Amount & Percentage (\%) \\
\hline 1 & Yes & 32 & 59.3 \\
2 & No & 22 & 40.7 \\
& Amount & 54 & 100 \\
\hline
\end{tabular}

Table 3 shows Distribution of Frequency of Home Ventilation at Infant House in Working Area of Gondomanan Health Center Yogyakarta. Based on the Table 3 is known that the amount of toddlers who stay in the home with unqualified ventilation as many as 28 toddlers $(51.9 \%)$ whereas toddlers that stays in the home with qualify ventilation as many as 26 toddlers $(48.1 \%)$.

Table 3. Distribution of Frequency of Home Ventilation at Infant House

\begin{tabular}{cccc}
\hline No & House Ventilation & Amount & Percentage \\
\hline 1 & Unqualified & 28 & 51.9 \\
2 & Qualify & 26 & 48.1 \\
& Amount & 54 & 100 \\
\hline
\end{tabular}

Table 4 shows Frequency Distribution of Occupants Density at Toddler House in Working Area of Gondomanan Health Center Yogyakarta. Based on the Table 4 is known that the amount of toddler that stay in the home with unqualified population density as many as 49 toddlers $(90.7 \%)$ whereas toddlers who stay in the home with qualify population density as many as 5 toddlers $(9.3 \%)$.

Table 4. Frequency Distribution of Occupants Density at Toddler

\begin{tabular}{cccc}
\hline No & Population Density & Amount & Percentage \\
\hline 1 & Unqualified & 49 & 90.7 \\
2 & Qualify & 5 & 9.3 \\
& Amount & 54 & 100 \\
\hline
\end{tabular}

Table 5 shows Frequency Distribution of Smoking Presence in Toddler Home in Working Area of Gondomanan Health Center Yogyakarta. Based on this table is known that the amount of toddlers who stay in the home that having the presence of smokers as many as 30 toddler houses $(55.6 \%)$ whereas toddlers who stay in the home without smokers as many as 24 toddlers $(44.4 \%)$.

Table 5. Frequency Distribution of Smoking Presence in Toddler Home

\begin{tabular}{cccc}
\hline No & The Presence of Smokers & Amount & Percentage \\
\hline 1 & Available & 30 & 55.6 \\
2 & Unavailable & 24 & 44.4 \\
& Amount & 54 & 100 \\
\hline
\end{tabular}




\subsubsection{Bivariate analysis}

Bivariate analysis is conducted to test the relationsip between independent variable and dependent variable. Chi-square test was employed in this analysis.

\subsubsection{Relationship of home ventilation with the incidence of pneumonia in infants in the working area of Gondomanan Health Center Yogyakarta}

Table 6 shows relation of house ventilation with pneumonia incidence among toddlers in. The result of bivariate analysis that has done, it gets $p$ value as many as $0.000(p>0.05)$ with score confidence interval include number 1 then statistically there is relation between home ventilation with incidence of pneumonia of toddlers in the working Area of Gondomanan Health Center of Yogyakarta. Based on the results on the table, it is known that the prevalence ratio (RP) of $2.786(\mathrm{RP}>1)$. It means that home ventilation is a risk factor for pneumonia.

Table 6. Relation of House Ventilation with Pneumonia Incidence among Toddlers

\begin{tabular}{lcccccccccc}
\hline \multicolumn{1}{c}{ Home } & \multicolumn{3}{c}{ Incidence of Pneumonia } & \multirow{2}{*}{ Amount } & \% & RP & CI & P5\% & value \\
\hline Ventilation & Yes & $\%$ & No & $\%$ & & & & \multirow{2}{*}{$1.535-$} & 0.000 \\
Unqualified & 24 & 44.4 & 4 & 7.4 & 28 & 51.8 & & 2.786 & 5.056 \\
Amalify & 8 & 14.8 & 18 & 33.4 & 26 & 48.2 & 100 & & & \\
\hline
\end{tabular}

3.1.2.2. The relationship of population density to the incidence of pneumonia for toddlers in the working area of Gondomanan Health Center of Yogyakarta

Table 7 describes relationship between population densities with pneumonia incidence. The result of bivariate analysis that has been done obtained $p$ value as many as $0.007(p>0.05)$ with the score confidence interval includes number 1 then statistically there is relation between population density with pneumonia incidence for the toddlers in the working area of Public Health Center in Gondomanan Yogyakarta. Based on the table's result is known that value of ratio prevalence (RP) is 2.043 (RP >1). It means the population density is a risk factor to pneumonia incidence.

Tabel 7. Relation between the Population Density with Pneumonia Incidence among Toddlers

\begin{tabular}{|c|c|c|c|c|c|c|c|c|c|}
\hline \multirow{2}{*}{$\begin{array}{c}\text { Population } \\
\text { Density }\end{array}$} & \multicolumn{4}{|c|}{ Incidence of Pneumonia } & \multirow{2}{*}{ Total } & \multirow{2}{*}{$\%$} & \multirow{2}{*}{$\mathrm{RP}$} & \multirow{2}{*}{$\begin{array}{c}\text { CI } \\
95 \%\end{array}$} & \multirow{2}{*}{$\begin{array}{c}P \\
\text { value }\end{array}$} \\
\hline & $\mathrm{Ya}$ & $\%$ & Tidak & $\%$ & & & & & \\
\hline Unqualified & 22 & 40.7 & 6 & 11.1 & 28 & 51.8 & \multirow{3}{*}{2.043} & & \multirow{3}{*}{0.007} \\
\hline Qualify & 10 & 14.8 & 16 & 33.8 & 26 & 48.2 & & $\begin{array}{l}1.211- \\
3447\end{array}$ & \\
\hline Amount & 32 & 59.21 & 22 & 40.79 & 54 & 100 & & 3.447 & \\
\hline
\end{tabular}

\subsubsection{The relation of smoker's presence with pneumonia incidence for the toddlers in working area} of Gondomanan Health Center Yogyakarta.

Tabel 8 informs relationship between smoker presence with pneumonia incidence among toddlers. The result of bivariate analysis obtained $\mathrm{p}$ value as many as with score confidence interval includes number 1 then statistically there is relation between population densities with pneumonia incidence. Based on the result is known that score of ratio prevalence (RP) as many as $2.04(\mathrm{RP}>1)$ it means the population density is a risk factor of pneumonia incidence.

Tabel 8. Relationship between Smoker Presence with Pneumonia Incidence among Toddlers

\begin{tabular}{|c|c|c|c|c|c|c|c|c|c|}
\hline \multirow{2}{*}{$\begin{array}{c}\text { House } \\
\text { Ventilation }\end{array}$} & \multicolumn{4}{|c|}{ Pneumonia Incidence } & \multirow{2}{*}{ Total } & \multirow{2}{*}{$\%$} & \multirow{2}{*}{$\mathrm{RP}$} & \multirow{2}{*}{$\begin{array}{c}\text { CI } \\
95 \%\end{array}$} & \multirow{2}{*}{$\begin{array}{c}\mathrm{P} \\
\text { value }\end{array}$} \\
\hline & Yes & $\%$ & No & $\%$ & & & & & \\
\hline Unqualified & 22 & 40.7 & 5 & 9.8 & 27 & 50 & \multirow{3}{*}{2.2} & & \multirow{3}{*}{0.002} \\
\hline Qualify & 10 & 18.5 & 17 & 31.5 & 27 & 50 & & $\begin{array}{l}1.303- \\
3714\end{array}$ & \\
\hline Amount & 32 & 59.21 & 22 & 40.79 & 54 & 100 & & & \\
\hline
\end{tabular}

\subsection{Discussion}

\subsubsection{The Relation of House's Ventilation with Pneumonia Incidence among toddlers}

Based on the bivariate analysis in statistical significance obtained the research's result that shows there is relation between house's ventilation with pneumonia incidence for the toddlers in working area 
Public Health Center Gondomanan Yogyakarta. In addition, it supports of biological significance value shows that the toddlers who stay in the house with unqualified ventilation has a risk 2.786 to pneumonia incidence than the toddlers who stay in the house with qualify ventilation.

Based on the result and measurement has been done by researcher, find the house with unqualified ventilation as many as $10 \%$. In the observation's result still found the house that has ventilation but it covered with plastic and gauze with dusty conditions that cause the air exchange to be not smooth, so that it causes humid condition in the house. Furthermore, there is still found house with permanent windows that cannot be opened, so that ventilation does not work optimally as a means of air circulation and will cause the supply of oxygen in the room is reduced. Homes that have little contamination of windows and ventilations will lead to the condition of a damp house and can be a good medium for the proliferation of pathogenic microorganisms cause a disease.

The research results show by the theory that contain the house unqualified ventilation give bad influence for the occupant, the unqualified ventilation house, the unavailability of unqualified ventilation will affect air circulation resulting in a lack of oxygen levels and increased carbon dioxide, the incidence of a stuffy odor, increased room humidity. The humidity in the room can increase because of process Liquid evaporation from the skin and absorption. Ventilation is one of the factors that affect humidity degree; the unqualified ventilations cause the humid room. The humid room can be a media for growth of pathogenic microorganisms, one of pneumonia streptococcus which is a pneumonia-causing microorganism. Furthermore, to get the good humidity degree, it should measure the air exchange is always smooth as well as the sunlight can enter with the repair of ventilation because the ventilation has relation with humidity [10].

The research by [11] that said there is relation between house ventilation with pneumonia incidence to the toddlers, this thing can be seen from the p value 0.011 and it signed by the score OR 2.374 means that the toddlers who live in the house with the unqualified ventilation can be a risk 2.374 to get exposure of pneumonia than the toddlers who live in the house with qualify ventilation. This is also supported by research [12] says that toddlers who live in homes with unqualified ventilation are associated with the incidence of pneumonia with a $p$ value of 0.026 . The results by a study conducted by [13] in Kenya which suggests bad ventilation will increase air pollution from the inhabitants and from outside the home that will cause a disease.

Based on the observation's result, there is the unique case is still found toddlers who live at home with qualify ventilation but having pneumonia as much as 8 toddlers $(14.81 \%)$, this thing can happen because toddlers have a history like previous disease such as Baby's Low Birth then it affects their immune systems are more susceptible to a disease, whereas contact with another people who have pneumonia it causes toddler infected with this disease. Furthermore, there are toddlers who stay in the house with unqualified ventilation but they do not have pneumonia because the activities of toddlers spend their time by playing outdoor, so reducing the risk of pneumonia-causing microorganisms present in the home.

The existence of poultry that researchers found in one of neighborhood Association in Prawirodirjan village can be one cause that can cause respiratory system disorders such as pneumonia, according to research by [14] said that people who put or bring poultry at home have the risk of suffering from respiratory system disorders as many as 1.14. The effect of existence the poultry in the surrounding environment is the smell that released during the decomposition process of poultry droppings. The smell may be derived from high ammonia gas and hydrogen sulfide $\left(\mathrm{H}_{2} \mathrm{~S}\right)$ gases, these smell compounds can be easily formed under anaerobic conditions such as wet poo bags. At higher ammonia concentrations in the air may cause respiratory distress in humans such as pneumonia [15].

\subsubsection{The Relationship between Population Density with Pneumonia Incidence among Toddlers}

Based on bivariate analysis, statistically it based on significance obtained the results of this study shows the significance value 0.007 which means there is a relationship between density of residents with the incidence of pneumonia for toddlers in the Working Area Public health center Gondomanan Yogyakarta, the toddlers who live in the house with unqualified population density is more suffer pneumonia as much as $40.7 \%$ or 22 toddlers. In addition, it supported by the value of biological significance that show toddlers who live at home with unqualified population density is 2.04 times greater for the incidence of pneumonia than toddlers who live in the home with qualify of population density.

Based on the field observation, it was noted the respondent's house were still found that the population density is unqualified as much as 28 houses. The population density can occur because unavailability of building area because the research location is located in Public Health Center Gondomanan precisely in Ngupasan district and Gondomanan district that located in the center of Yogyakarta which is a difficult location to get a house. Moreover, in the Gondomanan district the habitation that located in riverside of Code River is congested and close to other homes. There are some factors that affect it can be happened, 
such as the rapid growth of population in the city with the number of people who are not equal by the residence because of the high price of land in the village.

Based on the research result that has been done in Public Health Center Gondomanan Yogyakarta, there are still found many houses that close for another houses and the condition around home is dirty. In addition some toddlers who have pneumonia live in a small house that occupied by many people with unavailability of unqualified ventilation, this condition can causes the toddlers attacked infectious disease like pneumonia. The researcher found a humid house that characterized a stuffy smell and the researcher is breathless if the researcher takes a long time in the room. Those things can be happened because decreased of oxygen level and followed by increased carbon dioxide.

According to the theory, population density is high in the house will affect the temperature in the room caused by the release of the body heat. The more the number of occupants of the house will be faster air in the room experiencing pollution, either pollution caused by gas or caused by bacteria or germs that cause the disease. The number of densely populated residents will also result in decreased indoor $\mathrm{O}_{2}$ levels and followed by increased $\mathrm{CO} 2$. The impact of $\mathrm{CO} 2$ gas increase is a decreasing air in indoor quality that allows germs to multiply faster, so it can be said that a small house with a denser population will increase the probability of disease transmission through droplets and direct contact [10].

According to research conducted by [16] states that the population density associated with the incidence of pneumonia (pneumonia incidence), this is indicated by the acquisition of an OR of 2.2. The results of this study were supported by previous research conducted by [17] at Pati, Public Health Center I, that under-residential under-resident density at 9.804 times experienced pneumonia compared to toddler who lived at home density of qualified occupants.

This study is also in line with the research conducted by Tiewsoh et al [18] which states that children with severe pneumonia can be caused by the density of the inhabitants while in the house. In a study conducted by Srivastava et al. [19] also mentioned that the density of the inhabitants contributed to the transmission of infectious diseases one of which is pneumonia where in his research seen those toddlers who live at home with high density of occupants are twice the risk to suffer from pneumonia. In addition, the results of a study conducted by [20] in Kenya stated that children with more than five siblings living at home with unqualified occupants are at greater risk of pneumonia with $\mathrm{RR}=3.2$.

The distribution of unique cases in this study is also still encountered, namely it still found toddlers who live at home with a density of qualified residents (qualify) but experienced pneumonia that is equal to $18.5 \%$ or 10 toddlers. This can happen because it is still found by people who have a habit of burning garbage whereas the condition of the settlement is categorized as solid which causes the smoke from the burning of the garbage will easily enter into the house and inhaled by the toddler which will cause disturbance of respiratory system, because the distance between the houses are close together. In addition, people's habits, especially toddlers who are in the location of smoking in the late evening causes more cigarette smoke and toddlers sometimes come together so that toddlers become passive smokers and inhale directly the cigarette smoke.

\subsubsection{Relationship of smoker presence with pneumonia incidence among toddlers}

Based on bivariate analysis to statistical significance, it gets the research result that show there is relation between smokers presence and pneumonia incidence for toddlers in Public Health Center Gondomanan Yogyakarta. Furthermore, it supported the value of biological significance that shows the toddlers with the member of family who smoking in the home have risk to 2.2 having pneumonia than the toddler's family who do not smoking in the home.

The field's observation, still found there is a family member who smoking in the home. Smokers are more actively smoking at rest and watching television, some of these active smokers are fathers toddlers, grandparents, uncle toddlers. The habit of people in Prawirodirjan Village who are in front of the house at work, the more people who smoking more smoke that produced, where toddlers are also near the area directly affected by this baby by cigarette smoke In addition to housing conditions adjacent to each other, cigarette smoke comes from many smokers will easily enter into the house so that toddlers who are in the house at risk of exposure to cigarette smoke. Some people are aware of the dangers of cigarettes but they claim to still not be able to eliminate smoking habits both inside and outside the home.

This is similar to the existing theory that cigarette smoke contains various types of chemicals that contain toxins. Cigarette smoke from family members in the same home as toddlers is one of the domestic pollutants that can cause toxic effects, especially for toddlers. Continuous exposure to cigarette smoke will cause respiratory problems and worsen the onset of respiratory tract infections in adulthood. The more cigarettes smoked by the family, the greater the risk of pneumonia [21].

The function of the lung organ is to breathe by entering the clean air and removing the dirty air from the body. Chemicals contained in cigarette smoke stimulate the surface of the respiratory tract cells 
resulting in the release of mucus or phlegm. The same thing happens with the stimulation of dust, viruses and bacteria during the flu. Durable mucus in the respiratory tract can be a breeding ground for bacteria that will cause pneumonia [22].

Previous research [23] in Nepal told that the results of parents who smoke at home may pose a greater risk for children to be exposed to pneumonia with OR 2.24. The results of this study are similar by [24] the result $p$ value 0.049 , it means there is relation between smoking habits of parents with the incidence of pneumonia for toddler.

The results of this research are also supported by [25] which mentions in the study of toddlers who are often exposed to cigarette smoke has a 3.2 times greater risk of exposure to pneumonia, especially if the smokers are mothers and fathers of toddlers. Research with similar results [26] in Mongolia said that there is relation exposure to cigarette smoke in the home with the incidence of pneumonia for toddlers with the value acquisition Confidence Interval 1.06-4.35. Furthermore, the other research that states a relationship between the presence of family members who smoke in the house with the incidence of pneumonia in infants, is research conducted by [27] in Public Health Center Sidorejo Kota Pagar with p value 0.002 and value OR is 5.743 that means toddlers who living in homes with family members that smoking at home have risk 5.743 times greater than toddlers who live at home with family members who do not smoke. For parents who have a smoking habit will make toddlers as passive smokers, by [28] told passive smoking will be more has risk of lower respiratory system disorders. The other research by [29] explained that a mixture of complexes from the production of cigarettes inside the home is called environmental tobacco smoke, which will increase the level of NO2 in the room so that it can endanger its inhabitants, especially for toddlers.

Previous research [30] explained in their research NO2 exposure accompanied by exposure to cigarette smoke above $1.5 \mu \mathrm{g} / \mathrm{m} 3$ was strongly associated $(\mathrm{p}<0.01)$ with pneumonia. Action that can be done to reduce the risk of exposure to cigarette smoke is to educate smokers not to consume cigarettes in the home, especially when there are the children, because cigarette smoke is one cause of high air pollution in the house. Similar with research [31] that looking for a relation of smokers with children that diagnosis of respiratory diseases in the Hospital Sakarya Maternity and Children Turkey, show that the children with the parents who smoke have the incidence of respiratory diseases is higher than for non-smokers.

\section{CONCLUSION}

At the end of this paper, it can be concluded that there is relation between house ventilation, population density, smokers presence and pneumonia incidence for the toddlers in Public Health Center Gondomanan Yogyakarta. House ventilation, population density, smokers presence are determinant factors of pneumonia incidence among toddlers.

\section{REFERENCES}

[1] A. Said, "Determinants of Treatment Behavior of Upper Respiratory Infection (ARI) Infection in Toddlers," Health Research Bulletin, vol/issue: 29(I), 2010.

[2] Ministry of Health Republic Indonesia, "Guidelines for the Control of Acute Respiratory Infections," Jakarta, Directorate General of Disease Prevention and Control, 2012.

[3] I. Rudan, et al., "Epidemiology and Etiology of Childhood Pneumonia," Bulletin of the World Health Organization, vol/issue: 86(5), pp. 408-16, 2008.

[4] Ministry of Health Republic Indonesia, "Indonesia Health Profile 2015,” Jakarta, 2015

[5] Yogyakarta Public Health Office, "Yogyakarta Health Profile," 2013.

[6] Yogyakarta City Health Office, "Monthly Reports of the Program Data General of Disease Prevention and Control Upper Respiratory Infection Public Health Center Gondomanan," Yogyakarta, 2016.

[7] A. Maryunani, "Child Health Science in Midwifery," Jakarta, Trans Info Media, pp. 7-17, 2010.

[8] A. Satiti, "Secret Strategy to Stop Smoking," Yogyakarta, Datamedia, pp. 32-46, 2011.

[9] S. Notoatmodjo, "Health Research Methodology," Jakarta, Rineka Cipta Publishing, pp. 37-41, 2014.

[10] S. Notoatmodjo, "Health Research Methodology," Jakarta, Rineka Cipta Publishing, 2003.

[11] H. Padmonobo, et al., "Relationship Factors of the House's physical environment with the incidence of pneumonia in the working area of Jatibarang Public Health Center, Brebes District," Journal of Environmental Health Indonesia, vol/issue: 11(2), 2012.

[12] M. Rahmiza, "Relationship of Home Physical Environment Condition with Pneumonia Incidence in Toddlers in Work Area of Ngesrep Public Health Center Semarang City," Undergraduate Thesis, Diponegoro University, Semarang Indonesia, 2015.

[13] N. W. Mouturi, "Risk factors for indoor air pollution in rural households in Mauche division, Molo district, Kenya," 2010.

[14] M. H. Herawati and N. Sukoco, "The Influence of Raising Livestock in the House against the Increased Risk of Acute Respiratory Tract Infection," Health System Research Bulletin, vol/issue: 15(1), 2011.

[15] M. Praja, “Gases Cause Air Emissions,” Yogyakarta, Kanisius Publishing, 2006. 
[16] A. G. Darkwa, "Risk Factors for Pneumonia in Children Under Five at Komfo Anokye Teaching Hospital, School of Public Health," University of Ghana, 2012.

[17] E. L. Sari and T. J. Suhartono, "Relationship between House Physical Environmental Condition with Pneumonia Occurrence in Toddler in Pati I Public Health Center," Journal of Public Health, vol/issue: 2(1), 2014.

[18] K. Tiewsoh, et al., "Factors Determining the Outcome of Children Hospitalized with Severe Pneumonia," BMC Pediatrics, vol. 9, pp. 15, 2014.

[19] P. Srivastava and A. Asit., "Predisposing Factors of Community Acquired Pneumonia in Under-Five Children," Journal of Lung Diseases and Treatment, vol/issue: 1(1), pp. 1000101.

[20] M. Cardoso, et al., "Crowding: Risk Factor or Protective FActor for Lower Respiratory Disease in Young Children," BMC Public Health, 2004.

[21] Ministry of Health Republic Indonesia, "Guidelines for the Control of Acute Respiratory Infections," Jakarta, Directorate General of Disease Prevention and Control, 2012.

[22] E. Syahriyanti, "Stop smoking,” Yogyakarta, Dara Ilmu Publishing, 2010.

[23] Karki, et al., "Risk Factors for Pneumonia in Children under 5 Years in a Teaching Hospital in Nepal," vol/issue: 12(4), 2014.

[24] A. Aprilioza and Y. Dadi, "Relationship of Smoking Habits to Parents at Home with Pneumonia Occurrence in Toddlers in Plered Public Health Center Working Area," Medical Faculty, University of Islam Bandung, 2015.

[25] Amorim P., et al., "Factors Associated with Complications of Community-acquired Pneumonia in Preschool Children," Orginal Article, vol/issue: 38(5), 2012.

[26] A. Dagvadorj, et al., "Hospitalization Risk Factors for Children's Lower Respiratory Tract Infection: A Populationbased Cross-Sectional Study in Mongolia," Scientific Reports, vol. 6, pp. 24615, 2015.

[27] N. Sugihartono, "Risk Factors Analysis of Pneumonia Occurrence in Toddlers in Public Health Center Sidorejo City Working Area," Journal of Environmental Health Indonesia, vol/issue: 11(1), 2012.

[28] T. Shil, et al., "Risk Factors for Respiratory Syncytial Virus Associated with Acute Lower Respiratory Infection in Children Under Five Years: Systematic Review and Meta-Analysis," Journal of Global Health, vol/issue: 5(2), 2015.

[29] K. Smith, et al., "Indoor Air Pollution in Developing Countries and Acute Lower Respiratory Infections in Children," University of Liverpool, United Kingdom, 2000.

[30] R. Williams, et al., "The influence of human and environmental exposure factors on personal no.2 exposure," $J$ Expo Sci Environ Epidemiol, vol/issue: 22(2), pp. 109-115, 2012.

[31] N. Cinar, et al., "Smoking Status in Parents of Children Hospitalized with a Diagnosis of Respiratory System Disorders," Bosn J of Bas Med Sci., vol/issue: 10(04), pp. 319-22, 2010. 